\title{
South-South Cooperation and the Geographies of Latin America-Caribbean Integration and Development: A Socio-Spatial Approach
}

\author{
Thomas Muhr \\ School of Arts, Humanities and Social Sciences, Habib University, Pakistan \\ Centre for International Education Research, University of Nottingham, Nottingham, UK \\ thomas.muhr@ahss.habib.edu.pk
}

\begin{abstract}
Structured around the case of South-South cooperation in the construction of "complementary economic zones" among the member states of the ALBA-TCP, Petrocaribe, CARICOM and MERCOSUR, this article argues for a socio-spatial approach to the study of the Latin AmericaCaribbean integration and development. Two interrelated arguments are developed: first, in contrast to methodologically nationalist approaches, which typically view the regionalisms that are to form the complementary economic zones as ideologically separate, incompatible or conflicting projects, a sociospatial approach in conjunction with a South-South cooperation analytical lens explains their commonality and, subsequently, their interrelatedness and convergence. Second, while this SouthSouth cooperation space is not per se non-capitalist, a socio-spatial analysis also facilitates "seeing" the production of a socialist "counter-space" within this South-South cooperation structure.
\end{abstract}

\section{Resumen}

Estructurado sobre el caso de cooperación Sur-Sur en la construcción de "zonas económicas complementarias" entre los estados miembros del ALBA-TCP, Petrocaribe, CARICOM y MERCOSUR, este artículo argumenta una aproximación socioespacial al estudio de las geografías de integración y desarrollo en Latino América-Caribe. Dos argumentos interrelacionados se desarrollan: en primer lugar, en contraste con aproximaciones nacionalismo metodológicas, las cuales consideran los regionalismos que forman las zonas económicas complementarias como ideológicamente separados, proyectos incompatibles o en conflicto, una aproximación socio-espacial en conjunto con una lente analítica de cooperación Sur-Sur explica sus características compartidas y, posteriormente, sus interrelaciones y convergencias. En segundo lugar, mientras este espacio de cooperación Sur-Sur no es per se no-capitalista, un análisis socio-espacial también facilita "ver" la producción de un "contra-espacio" socialista en esta estructura de cooperación Sur-Sur.

\section{Keywords/Palabras Clave}

development, space, South-South cooperation, socialism, regionalism, Latin America-Caribbean desarrollo, espacio, cooperación Sur-Sur, socialismo, regionalismo, Latino AméricaCaribe 


\section{Introduction}

A series of meetings and summits involving 27 sovereign Latin America-Caribbean states plus the British Overseas Territory Montserrat since February 2012 has led to the declared intention of creating "complementary economic zones", on the one hand among the 24 member states of the Bolivarian Alliance for the Peoples of Our America-Peoples' Trade Agreement (ALBA-TCP), Petrocaribe, and the Caribbean Community (CARICOM) (Zona Económica Complementaria ALBATCP/Petrocaribe/Caricom; ALBA-TCP 2015: Point 12), and on the other hand among the 28 members of the ALBA-TCP, Petrocaribe, CARICOM and the Common Market of the South (MERCOSUR) (Zona Económica Complementaria entre MERCOSUR, ALBATCP, CARICOM y Petrocaribe; MERCOSUR 2014a). ${ }^{1}$ With overlapping memberships (see Appendix 1), and not in existence as yet, these projects are to be governed by the South-South cooperation principles of "complementation", "solidarity" and "cooperation", established as such by the 1967 Group of 77 (G-77) Charter of Algiers, with the objective of promoting "fair trade" and "productive integration" while reducing "economic asymmetries", "poverty" and "social exclusion" (ALBA-TCP 2015; MERCOSUR 2014a, 2014b). Unlike North-South "aid", South-South exchanges pursue "equal and reciprocal relationships" among "developing countries", "non-interference", and eschewing of "political conditionality" (UNDP 2013: Table 2.2; UNESCO 2014:49; also Chaturvedi 2012; Mawdsley 2012). Much of the Latin America-Caribbean international studies literatures (international relations, international political economy, international politics), however, perceive the regionalisms that are to form these economic zones as ideologically separate, incompatible or conflicting political projects, whose coexistence allegedly drives "fragmentation" rather than integration (e.g. Briceño-Ruiz 2010:218; Serbin 2007). In this view, CARICOM and MERCOSUR, as so-called neoliberal outward-oriented "open regionalisms", 2 are frequently counter-posed to "post-neoliberal" ALBA-TCP/Petrocaribe. As Gian Luca Gardini (2015:214, 216217) reiterates:

integration models largely based on free trade are still alive (CARICOM, Mercosur, CAN [Andean Community], NAFTA [North American Free Trade Agreement]) ... Countries subscribe to many different agreements, some even contradictory ... The compatibility of ALBA and CAFTA-DR [Dominican Republic-Central America Free Trade Agreement] rules (Nicaragua) or ALBA and Mercosur principles (Venezuela) or ALBA, UNASUR [Union of South American Nations], CAN and soon Mercosur commitments (Bolivia) is at least questionable.

\footnotetext{
${ }^{1}$ For a graphic depiction of this process between February 2012 and July 2014, see Muhr (2015a: Appendix II). ALBA-TCP and Petrocaribe have been theorised as one political project (Muhr 2008, 2011), which is manifest in shared institutions (e.g. ALBA Bank, ALBA Caribe Fund). They will therefore be referred to as ALBA-TCP/Petrocaribe. I would like to thank Jessica Byron (email communication; 8 July 2015) for pointing out that in the absence of proper CARICOM declarations in support of the establishment of the complementary economic zones, most CARICOM member governments have supported these initiatives through their ALBA-TCP/Petrocaribe memberships and MERCOSUR associate memberships (as in the case of the Co-operative Republic of Guyana and Republic of Suriname).

${ }^{2}$ Characterised as extensive, unilateral trade liberalisation and de-/re-regulation for vertical, competition-based insertion into global capitalism (ECLAC 1994). See Aponte-García (2014) and Girvan (2011) for discussions of the adverse developmental impact of "open regionalism" in Latin America-Caribbean.
} 
Underlying such interpretations is an ahistorical, methodologically nationalist approach to Latin America-Caribbean cooperation through which regions are perceived as static blocks of homogenous (nation-)states. This article, by contrast, advocates for a socio-spatial methodology in conjunction with a South-South cooperation analytical lens to explain the commonality and, subsequently, interrelatedness and convergence, of the ALBA-TCP/Petrocaribe, CARICOM and MERCOSUR (for a general discussion of the raison d'être of a socio-spatial methodology, see Agnew 1994; Jessop et al. 2008).

The article develops as follows: a methodological discussion of space, scale and uneven development in the next section will be followed by a historically grounded analysis of the South-South cooperation dimension in the ALBA-TCP/Petrocaribe, CARICOM and MERCOSUR. This provides the basis for the argument of a socially produced South-South cooperation space. The conclusion extends this argument, stating that while South-South cooperation is not per se non-capitalist, a socio-spatial analysis also permits "seeing" the production of a socialist "counter-space" (Lefebvre 1991) within this South-South cooperation structure. To this end, some initial conceptual clarifications are indispensable. First, a "region" here principally denominates an inter- or supranational unit, as in International Relations (regionalisms such as ALBA-TCP/Petrocaribe, CARICOM, MERCOSUR), but will in the discussion of uneven development also be used in the Geographers' sense of an intra-national area. In both cases, however, regions are understood as socially constructed rather than geographically designated "self-evident blocks of terrestrial space" (Agnew 2013:12).

Second, South-South cooperation as promoted in the 2000s and the first half of the 2010s by such "leftist" governments as of the Argentine Republic, Plurinational State of Bolivia, Federative Republic of Brazil, Republic of Cuba, Republic of Ecuador, Republic of Nicaragua, Eastern Republic of Uruguay, and Bolivarian Republic of Venezuela is associated with endogenous and socialist development thinking and Third World independence, self-determination and collective self-reliance (see Ayllón and Ojeda 2013; Ayllón et al. 2014; Michelutti 2012; Muhr 2016a; de Sá e Silva 2009). By "leftist" or "progressive" I mean social and political forces that, "unreconciled" with the supposed inevitability of global inequalities and injustices, fight for egalitarian "alternatives" (Santos 2001:209). As an "alternative" to neoliberalism (Sunkel 1993:2), or the global process of neoliberalisation (Tickell and Peck 2003) - associated with "Washington Consensus" structural adjustment politics of privatisation, de-/re-regulation and liberalisation (finance/capital, trade, labour), welfare cutbacks, and the fundamental value of individualisation (Harvey 2005) following Osvaldo Sunkel (1993) and collaborators, endogenous development is a neo-structuralist approach that involves selective-strategic state intervention for regulation (e.g. finance), deprivatisation, transformation of the productive structure, and equity-enhancing (basic) needs-based redistribution (Sunkel 1993; also Bitar 1988; Ffrench-Davis 1988). ${ }^{3}$ Seeking structural transformation, endogenous development disrupts neoliberalisation and has provided a basis for transition to socialism (e.g. Muhr 2008, 2011, 2013; Republic of Ecuador 2009). This -

\footnotetext{
${ }^{3}$ Sunkel (1993) directly informed the Venezuelan government's endogenous development strategy (see MINCI 2004; also Michelutti 2012; Muhr 2008:179-85). Other Latin America-Caribbean national development plans also make reference to "endogenous development" (rather than to neostructuralism), e.g. Federative Republic of Brazil (2007) and Republic of Ecuador (2009).
} 
socialism - is here associated with necessity according to human need (use value over exchange value) and the abandonment of the capitalist principle of profit maximisation (Smith 2010:89). Thus, "distributive socialism", Harvey insists (evoking Marx's Critique of the Gotha Programme), seeks the democratic management and regulation of capitalism to ensure basic needs satisfaction through state intervention, in contrast to communism as the creation of "an entirely different mode of both the production and distribution of goods and services" (Harvey 2011:224-225). Subsequently, third, since "a capitalist society is far more than the capitalist mode of production" (Massey 1995:17), constructing "socialism" requires (in accordance with the multidimensionality of development) holistic transformation beyond the political economic, integrating "class justice" (productive, appropriative, distributive) (DeMartino 2003) with social, political, legal, economic, cultural, gender, and environmental justice (see Anton and Schmitt 2007; Harvey 2010; Muhr 2008, 2013; Radice 2009). The examples presented in this article will underscore, first, that South-South cooperation in the ALBA-TCP/Petrocaribe, CARICOM and MERCOSUR displays such multidimensionality; and, second, while this South-South cooperation is not per se non-capitalist, it drives a rights-based destabilisation of the capitalist principles of profit maximisation and competitive locational advantages through human needs-based and equity-enhancing practices. As central to the sociospatial methodology, these practices are not isolated instances (sometimes dubbed "pockets of resistance") but are structurally interconnected within and across territories in the production of space/scale.

\section{Methodological Considerations on Space, Scale and Uneven Geographical Development}

It is beyond the scope of this article to undertake a review of the varied and contested Marxist and post-structuralist approaches to space/scale since the challenge of positivist spatial science in the 1960s (e.g. Moore 2008; Smith 2010: chapter 3). Rather, the following conceptual explorations follow Danny MacKinnon's (2010) reasoning of a compatibility of more "open strands" of political economic sociospatial theorising (e.g. Harvey 1996, 2000; Lefebvre 1991; Sheppard 2012; Smith 1992a, 1992b; Swyngedouw 1997) and "poststructuralist-inspired" approaches that do not dismiss the material altogether (e.g. Marston 2000; Marston and Smith 2001; Massey 1994, 1995, 2005). Accordingly, a broader understanding of "social" than "social relations of production" (and "society" not reduced to "mode of production") is adopted, as multidirectional, simultaneous and dialectical cultural, ecological, economic, legal, infrastructural, judicial, political and social relations, flows, processes and material and discursive practices and activities (see Howitt 1993; Marston 2000; Massey 1999; Paasi 2004; Smith 1992a, 1992b; Swyngedouw 1997). Following Harvey (2006a), the subsequent discussions draw from three conceptions of geographical space: absolute space (fixed, bounded territories, such as administrative units, private property, states); relative space (the relative locations of "things", which depends on the spatio-temporal framework of the observer and what social phenomenon is being studied); and relational space (the production of spatiotemporality through processes). These co-existing spatialities are in "dialectical tension with each other" (Harvey 2006a:276), and analytical reduction to either of them - as international studies approaches do with respect to absolute space (nation- 
state territories) - produces misleading results. It should be noted that a socio-spatial methodology means neither to repudiate the state nor to discard national territorial space and state power over that space, which is of primary relevance for instance with respect to legislation and government- and/or state-led cooperation through which processes and political projects as analysed in this article are either supported or contested. Furthermore, for the methodological purpose of this article and its structuralist focus, excluded from consideration are issues of agency and power (class, ethnic, environmental, gender, cultural struggles), through which the production and rearticulation of space/scale is mediated and continually contested (see Harvey 1990:237; Jonas 1994:262; Lefebvre 1991:44, 55; Massey 2005:9; Swyngedouw 1997). ${ }^{4}$ Therefore, the ongoing struggles over government and state power and the dialectics involved cannot be given the attention they would deserve in a more general discussion of processes of structural transformation.

Arguing for a socio-spatial approach to regionalism and South-South cooperation in Latin America-Caribbean may usefully start with the notion of "methodological nationalism", as it has been problematised across the critical social sciences in recent decades. By neglecting "trans-national phenomena" (Martins 1974:277), methodological nationalism is a "nation-centred lens that defines nations as natural units of analysis" (Amelina et al. 2012:2), spatially conceptualised in absolute (territorially bounded), essentialist terms as an inert, static and timeless backdrop or "container" of societies and social action (Agnew 1994; Brenner 2004; Harvey 2006a; Sheppard 2012; Smith 2010; Taylor 1994). By contrast to such a substantivalist ontology and its assumption of pre-formed, coherent "self-acting entities" or "things", and actions taking place only among these fixed and unchanging units, a relational ontology depicts social reality "in dynamic, continuous, and processual terms" (Emirbayer 1997:281-286). All "things" (elements, structures, systems) in the social and material worlds, as has been argued, are continuously constituted, reconstituted and undermined through dialectical processes, flows and relations (Harvey 1996:4668; Massey 1995:326). A relational ontology thus “"opens' the traditional state-as-amonolith centric view" (Moisio and Paasi 2013:256).

Regarding space/scale, the following premises are salient. First, space is produced (and lived and changed) through social practices (actions) (Lefebvre 1991:12, 33). Space as a "product of interrelations" ("relations" as "embedded material practices"; Massey 2005:8) implies that space is not produced in isolation from time: social processes and relationships "create/define space and time" rather than occurring "in space and time" (Massey 1994:263). Second, socially created space has a materiality as well as an ideological content (Lefebvre 1991:31, 44). Different socio-cultural practices produce "different forms of space-time" (Harvey 1996:215) and, conversely, the spatial influences "the form of social relations" (Massey 1995:337). This "historical dialectic" or "unity" of society and space (Smith 2010:106-107), or "socio-spatial dialectics" (Soja 1989), implies that different political projectsneoliberal, endogenous, socialist — produce "a simultaneous multiplicity of spaces" (Massey 1994:3); spaces which "interpenetrate one another and/or superimpose themselves upon one another" (Lefebvre 1991:86). Such "coexisting heterogeneity" (Massey 2005:9-11) entails recognising "that there is more than one story going on in

\footnotetext{
${ }^{4}$ Inter alia conceptualised as: "power geometry" (Massey 1999); "politics of space" (Lefebvre 1991:60; Massey 2005); "politics of space-time" (Massey 1999); "politics of scale" (Smith 1992a), "scale politics" (Jonas 1994) or "scalar politics" (MacKinnon 2010).
} 
the world and that these stories have, at least, a relative autonomy" (Massey 1999:35). Third, as "always in process" and "never a closed system" (Massey 2005:11), "the spatial" is "open" and "dynamic", "constructed out of the multiplicity of social relations across all spatial scales, from the global reach of finance and telecommunications, through the geography of the tentacles of national political power, to the social relations within the town, the settlement, the household and the workplace" (Massey 1994:4).

This view of the spatial as cross-scalar "stretched-out social relations" (Massey 1994:4) has implications for a conceptualisation of scale - scales as institutionalised sets of practices and discourses (Paasi 2004:537), "implicated in" (Marston 2000:219) or "integral to" (Marston and Smith 2001:616) the production of space.

Categorisations of scale include: the body, household and other local and sub-national (e.g. building; community; municipal government; ecological niches), national (e.g. nation-state governments), inter- and transnational (e.g. cross-border regionalisms; transnational communities), regional (supranational regionalisms) and global (e.g. finance flows) scales. Therefore, the significance of such scalar terms depends on the distinctive social processes (localisation, regionalisation, globalisation, and so forth) or organisational and institutional forms to which they refer and are not "static entities frozen permanently into geographical space" (Brenner 2004:7, Box 1.2). On the one hand, rather than viewing scaling processes as "the production of differentiated spatial units" (Paasi 2004:538), or "scaled spaces" (Swyngedouw 1997:144), which suggests a uni-scalar imaginary of space (which might be true for absolute space; see Smith 2010:196), relational space is here viewed as extending across, or traversing, a plurality of interrelated scales produced in the processes of space production. As Becky Mansfield states, "events and phenomena"- such as political projects and the spatialities that they produce- - "can, and should, be understood as being simultaneously global, regional, national, local and even bodily" (2005:468). Thus viewed, scale structures (Smith 1992b:72) or "differentiates" space (Marston and Smith 2001:615). On the other hand, rather than a fixed hierarchical (often referred to as "nested") arrangement (for which "level" would do) (Howitt 1993, 1998), scalar configurations are perpetually (re) constituted and redefined through social praxis, "in terms of their extent, content, relative importance, and interrelations" (Swyngedouw 1997:141). While a certain "tension between fixity and fluidity in scale conceptualization" (Moore 2008:205) has been noted - a tension between essentialist and constructionist approaches - such socially produced scales as the (nation-)state (as part of previously constructed, "pre-existing scalar structures"; MacKinnon 2011:30) arguably do have greater fixity than (emerging) scales produced through South-South cooperation.

There is widespread agreement among geographers in particular that capitalism continually (re)creates structures of socio-spatial inequalities, and that uneven development at "all spatial scales" (Smith 2010:132) has exacerbated during global neoliberalisation (Brenner 2004, 2010; Harvey 2006b:101; Sheppard 2012:62; Smith 1997). As a socio-spatial "core-periphery polarization", this means that inequalities express themselves socially (e.g. class and income stratification) as well as spatially "through the polarization of development among different territories, regions, places, and scales" (Brenner 2004:13). Uneven development thus involves "an acute differentiation and continued differentiation of relative space, both between and within scales" (Smith 2010:196). For example, the socio-spatial integration of a place 
of production into global capitalism alters its relative position (while its absolute location remains unchanged) (Smith 2010:113). Brenner (2010:42) categorises these different, permanently reworked relations of socio-spatial divisions ("scaledifferentiation") as: intra-place (e.g. intra-urban neighbourhoods); urban (industry)/rural (agriculture); global core/periphery zones; interplace/interurban, including city-regions and intranational regions (not understood in administrative terms as pre-given entities but as any sub-national area of any size, Massey 1995:11); and supranational/regional institutionally demarcated spaces, such as the European Union (EU), but also ALBA-TCP/Petrocaribe, CARICOM and MERCOSUR.

Uneven development is the outcome of the dialectic of the "geographical equalization of conditions and levels of production" (Smith 2010:202) through competing capitalists replicating profit-maximising strategies and "geographical differentiation" produced by capital seeking competitive locational advantages through the spatial or territorial division of labour and other locational assets (Smith 2010:135, 203; also Brenner 2004:13; Massey 1995: Chapter 4). As symptoms of dispossession and exclusion (Harvey 2006b), uneven spatial development can more generally be understood as produced by a concentration of wealth and power and socio-economic opportunities in selected locations and among distinct social classes (Harvey 2000:81; Massey 1994:50-51): investment in infrastructure, services and utilities (water, sanitation, housing, electricity, education, health care) becomes concentrated in the centres of production, finance and commerce, as it is there where they are likely to be most profitable (Harvey 2006b:101-102). In sum, contemporary geographies of uneven development are pluri-scalar, produced not only by inter-national (as in classical dependency theory and world systems analysis) but also intra- and transnational core-(semi)periphery relations (Brenner 2004: Chapter 5).

\section{Constructing a Latin America-Caribbean South-South Cooperation Space}

Different development projects have distinct spatial repercussions, and spatial structures can be transformed through development politics (Massey 1995:82-85). This is cogently demonstrated in Brenner's (2004: Chapter 5) analysis of the transition from "spatial Keynesianism" to neoliberal "urban locational policy" in Western Europe. There, in the context of the economic crisis of the 1970s and the decline of national subsidies and external investment, endogenous development became a sub-national (local/regional) scale counter-strategy by leftist social and political forces (promotion of economic growth and employment through local technological innovation) in an effort of preserving the Fordist-Keynesian achievements of social redistribution and territorial equalisation (national state regulation to confront uneven geographical development). In the contemporary Latin America-Caribbean contexts, however, endogenous development is a national state policy that has been "upscaled" as (regional and global) South-South cooperation (see Muhr 2010, 2011, 2013). This should not suggest that social relations in the respective national territories, nor in the territorial spaces of ALBA-TCP, CARICOM and MERCOSUR, are universally, homogenously and coherently defined by the South-South cooperation principles. As global capitalist structures decidedly 
penetrate all member state territories (finance, production, trade, consumption), ${ }^{5}$ the South-South cooperation space produced does not coincide with the absolute ALBATCP/Petrocaribe, CARICOM and MERCOSUR spaces, nor of the envisioned complementary economic zones. Prior to empirically illustrating this by identifying the South-South cooperation dimensions in the ALBA-TCP/Petrocaribe, Caricom and MERCOSUR, two considerations should be highlighted. First, while Latin AmericaCaribbean endogenous development maintains economic growth and competitive insertion in global capitalism, it has equally been conceptualised as a spatial approach to alleviating uneven development (Sunkel 1993:57). In accordance with "from within" meaning the community extending out from the local to the national, regional and global (MINCI 2004:4), the construction of this space involves "payment of the social debt" (Sunkel 1993:51) and a structural deconcentration of ownership towards worker-run micro, small and medium enterprises and cooperatives, which should receive preferential treatment in international cooperation and integration (AponteGarcía 2014:109-112; Bitar 1988:56-58; Ffrench-Davis 1988:41). ${ }^{6}$ Therefore, on the one hand, endogenous development involves a rights and justice based deprivatisation and decommoditisation of such social goods and services as cooking gas, education, food, health and housing, which in contrast to assistentialist and compensatory measures seeks to contribute to structural transformation (see, especially, Muhr 2008, 2011, 2013). As Harvey states, "strict enforcement" of human rights may "entail massive and in some sense revolutionary transformations in the political economy of capitalism" $(2000: 90,93)$. On the other hand, historically transitions to socialism have not per se excluded non-state forms of social ownership and employment, that is, micro and small productive enterprises, especially family smallholders and cooperatives (Massey 1987; Nove 1983). This rests on the argument that profit in such forms of social organisation is made primarily from labour (including the owners) rather than simply from ownership of land or capital (Nove 1983:207), and small and middle-sized capital may follow social and political interests other than strictly monetary ones (Massey 1995:308). Decisive then is state regulation of the accumulation process, i.e. of labour, ownership of/control over financing (investments, credits), price and commercialisation, and socialised surplus appropriation and distribution (e.g. through taxation, social insurance, public services) (Massey 1987:40; Nove 1983: Part 5). Such intervention has been observed, albeit not equally and evenly in all the national contexts of the envisioned complementary economic zones, however, most notably perhaps in Cuba (Ludlam 2012), Ecuador, Nicaragua and Venezuela (Muhr 2013). Endogenous development thus cannot indiscriminately be associated with profit maximisation and private accumulation and appropriation, and endogenous development has had significant equity-enhancing redistributional effects in national contexts in which such strategies have been deployed. ${ }^{7}$ While a socialist strategy would involve alleviating spatial inequalities,

\footnotetext{
${ }^{5}$ Intra-national socio-spatial differentiation is the product of not only national or intranational processes but also of the position of a particular nation in the global division of labour (Massey 1978:118). Girvan (2011:169-171), despite a methodological nationalist approach, in fact shows this in his study of the co-existence of social relations associated with ALBA-TCP, CARICOM and the (neoliberal) European Union Economic Partnership Agreement in the territories of Antigua and Barbuda, Dominica and St Vincent and the Grenadines.

${ }^{6}$ In contrast to large companies, small enterprises are not only constrained by lower financial resilience and limited capital for investing in technological innovation, but are also less able to respond to changing competitive cost pressures through geographical mobility due to their social embeddedness in family and community structures (Massey 1995:155-159).

${ }^{7}$ As an indicator of redistribution, Gini coefficients were significantly reduced in Argentina (urban),
} 
this should not mean "some rigidly conceived "even development" but the creation of "socially determined patterns of differentiation and equalization which are driven not by the logic of capital but by genuine social choice" (Smith 2010:211). Equally, as spatial inequality is likely to exist in any society, decisive is whether the fact of uneven development is strategically used for competitive accumulation and profit maximisation (Massey 1994:50-51).

Second, South-South cooperation constitutes a "counter-dependency" strategy: unlike dependency as a relation of inequality grounded in the subjection and structural conditioning of (semi)peripheral economies to the interests of transnational capital ("the global division of labour") and an inherent "absence of actor autonomy", dependence as "asymmetric inter-dependence" is a relation of "mutual control" and "reliance" despite "structural asymmetries", and, therefore, legitimate if consensual (Caporaso 1978). As autonomy or "total self-reliance" for resource-poor nations appears unachievable, "controlled dependence" is a more egalitarian relation in which the partners can "affect the fundamental nature of their relationships" (Erisman 1991:143). Thus, while the principles of solidarity, complementarity and cooperation may (and in practice do) involve altruism, commercial, political and ideological interests are equally part of South-South relations. However, this does not axiomatically translate into a competitive market and profit maximisation logic. For example, depending on the partner's economic situation, Cuban socialist internationalism, which has been instrumental in Latin America-Caribbean SouthSouth cooperation, has at times charged (variable) commercial rates for services, however below world market prices (Domínguez 1989; Erisman 1991; HicklingHudson et al. 2012). In the Cuba-Brazil medical cooperation since 2014, for instance, such a "win-win" relation, which South-South cooperation is frequently associated with, has been generated among the states of Brazil (cost reduction by over half per doctor) and Cuba (revenues of approximately US\$3950 per doctor), as well as the Cuban medical personnel (increases in personal remuneration from approximately US\$60 to 1245 per month) (Kirk et al. 2015:9). While, after decades of neoliberalisation, private surplus value appropriation appears to be inevitably part of South-South cooperation (as for instance in the case of the Brazilian company Odebrecht), reciprocal non-monetary benefits may nonetheless be generated, such as with respect to experience, knowledge and cultural exchange, capacity building, diplomatic solidarity, human rights promotion, and the political recognition of "the South" itself (Muhr 2016a).

The remainder of this section sketches out the historical emergence of South-South cooperation in the ALBA-TCP/Petrocaribe, CARICOM and MERCOSUR. The intention is neither to exhaustively discuss these projects nor to present "country" cases. Rather, instances of South-South cooperation at different scales produced through these processes and relations are purposefully selected, in order to also

from 0.578 (2004) to 0.475 (2012); Bolivia, from 0.614 (2002) to 0.491 (2013); Brazil, from 0.639 (2001) to 0.548 (2014); Ecuador, from 0.513 (2002) to 0.447 (2014); Nicaragua, from 0.579 (2001) to 0.478 (2009), however the anti-neoliberal government led by President Ortega only entered office in January 2007, and alternative measures suggest a reduction to 0.38 in 2014 (INIDE 2015:23); Uruguay (urban), from 0.455 (2002) to 0.379; Venezuela, from 0.500 (2002) to 0.407 (2013, new measurement method) (CEPAL 2016: Table A1.3). Out of 16 Latin America-Caribbean nations surveyed, between 2010 and 2014, Uruguay, Argentina and Ecuador most significantly reduced their Gini coefficients, by $2.7 \%, 2.3 \%$ and $2.2 \%$ annually, respectively (CEPAL 2016:13). 
include examples of socialist logics and practices. In both respects, the literature cited provides further empirical details and case studies. On this basis, the conclusion will argue for the emergence of a socialist "counter-space" within this South-South cooperation spatial structure.

\section{ALBA-TCP/Petrocaribe}

Among the three regionalisms discussed here, the ALBA-TCP/Petrocaribe associated agreements and treaties define most explicitly the adopted South-South cooperation principles: solidarity as the "commitment to mutual support and joint efforts to achieve sustainable and integral human development, and the appropriate care of countries' emergent needs, within the possibilities and in accordance with shared responsibilities"; complementarity as the "commitment to identify and develop joint projects that permit the integration and/or synergies of the capacities in accordance with their [partners'] potentialities and interests"; and cooperation as "strategic alliances of mutual benefit" (Muhr 2010: Table 1). This normative framework derives from ALBA-TCP/Petrocaribe founding members' Republic of Cuba and Bolivarian Republic of Venezuela South-South cooperation trajectories. As the only Latin American-Caribbean state the Cuban Revolution participated as a member with full rights in the founding meeting of the Nonaligned Movement (NAM) in Belgrade (then Yugoslavia) in 1961, regarded as a milestone in the evolution of South-South cooperation (Domínguez 1989:221; Furtak 1985:348). Between 1975 and 1989, the Cuban government allocated between $0.33 \%$ and $0.37 \%$ of gross domestic product (GDP) to development cooperation (Alvarez González 2000) while assuming "a leading role" in the promotion of the United Nations New International Economic Order (Erisman 1991:142). Altruistic cooperation, although reduced, was maintained in the context of the collapse of the Soviet Union, and became re-intensified at the global scale from the late 1990s onward (culture, education, health, sports) (Alzugaray Treto 2006; De Vos et al. 2007; Hickling-Hudson et al. 2012; PNUD 2003).

In Venezuela, South-South cooperation became enshrined in the legal and policy architectures with the Chávez presidency from 1999 on, as the promotion of the New International Economic Order was resumed (Bolivarian Republic of Venezuela 2001:155-158; Chávez Frías 2005). Accordingly, in 2000 the Venezuelan government unilaterally extended the 1980 "San José Oil Accord" (formally Economic Cooperation Programme for Central American Countries) through which the governments of Mexico and Venezuela had committed themselves to supplying 11 Central American and Caribbean nations with 160,000 barrels of oil and derivatives per day under a concessional financing scheme, considered the "first collaborative aid effort between an OPEC and non-OPEC country" within the rationale of South-South cooperation (Grayson 1985:394). This built on consecutive Venezuelan administrations' growing cooperation with CARICOM (and individual members thereof) from the 1960s onward, leading to a preferential trade agreement with CARICOM in 1991, as well as becoming a donor member of the Caribbean Development Bank (Byron 2015). The progressive bilateral extension of the San José Oil Accord in the first half of the 2000s in conjunction with the 2000 Cuba-Venezuela 
Integral Cooperation Agreement produced ALBA-TCP and Petrocaribe in 2004 and 2005, respectively (e.g. Muhr 2008, 2011, 2013).

ALBA-TCP/Petrocaribe cooperation drives a transition to socialism by operationalising (inter alia) "tariff protection for infant industries", "concessionary treatment of smaller and weaker economies", and "the rights of labour" (Girvan 2011:164-168). The (re)distribution of Venezuelan petroleum and gas resources (and surpluses therefrom) at a regional scale "alleviate[s] inherited uneven spatial development" by replacing the orthodox competitive "comparative advantage" by the "cooperative advantage" (Muhr 2008:184, 263). Thus state energy enterprises, which are established in territories where no such infrastructure exists, ${ }^{8}$ (re)claim control over the energy value chain, while the concessionary financing scheme sustains bilaterally and regionally administered social and socio-productive development funds within a basic needs, not-for-profit rationale. By 2014, 432 such projects had been funded within the Petrocaribe member territories, of a total value of US $\$ 3944$ million (SELA 2015). Other examples of socialisation include: deprivatisation and decommercialisation of tertiary education (Muhr 2011); the ¡Yo, Sí Puedo! ("Sure I Can!") literacy and Misión Milagro ("Mission Miracle") ophthalmological programmes, from which over 7.2 million impoverished people in almost all Latin American-Caribbean (national) territories (and beyond) had benefitted by 2014 (ALBA-TCP 2014). These programmes operate outside the market logic as "[q]ualification for treatment does not follow any capitalist 'investment viability' rationale" since "no age restriction" is applied (Muhr 2011:202); the creation of state and community media and cinema companies (e.g. the Venezuelan Villa del Cine or "Cinema City"), contributing to the formation of a collective identity of the South (Villazana 2013); and the creation of multi-state "grandnational enterprises" (empresas grannacionales) as "lead enterprises" for "controlling and coordinating" regional production and "fair trade" chains and networks, incorporating diverse forms of hitherto isolated local scale instances (small and medium private, public-private, and communal ownership) and oriented towards the production of use value for basic needs satisfaction in the intra-ALBA-TCP market (Aponte-García 2014: Chapter 5). As basic needs satisfaction is viewed as a "fundamental human right", grandnational enterprises may apply such measures as subsidisation and "expropriation", while surpluses are either invested in the enterprise or socially appropriated and redistributed via social programmes (Califano 2015:116). Indicative of counterdependency effects are, first, a significant increase (42\%) in international intra-ALBA export trade between 2005 and 2011 (compared with the previous seven years among the respective nations) (Aponte-García 2014:207-208); and, second, a reduction of "systemic value extraction" from ALBA-TCP members Bolivia, Ecuador and Venezuela (i.e. an increase in the proportion of surplus value retained in their territories) in comparison to the "open" neighbours Chile, Colombia and Peru (Higginbottom 2013).

\section{CARICOM}

\footnotetext{
${ }^{8}$ By May 2016, US\$1600 million have been invested in the Petrocaribe member territories in the construction of this logistical infrastructure (Petrocaribe 2016).
} 
South-South cooperation in CARICOM has to be understood in relation to the overlapping formal ALBA-TCP/Petrocaribe-CARICOM memberships (see Appendix 1) and the historical relation(s) of CARICOM (and individual members thereof) with Cuban socialism. Constituted in 1973 via the Treaty Establishing the Caribbean Community, the Common Market Annex to the Treaty (CARICOM 1973) contains the developmentalist principles of protectionist regional import substitution industrialisation (Articles 17b, 49, 56) for greater collective self-reliance through "coordination and collaboration" (Article 39), "industrial programming" including regional production chains (Article 46), "ownership and control of regional resources" (Article 44) and maximising "complementarity between industries and economic sectors" (Articles 45-49). Solidarity with less developed members is expressed through the aim of the more developed members sharing technological and research facilities (Article 60) and in the establishment of the Caribbean Development Bank funding programmes and concessions/exemptions. ${ }^{9}$ However, the 2001 Revised Treaty of Chaguaramas Establishing the Caribbean Community including the CARICOM Single Market and Economy reinstituted CARCIOM as neoliberal "open regionalism", a process that already started in 1989 (Girvan 2011). Nonetheless, despite increased emphasis on free market mechanisms and furthering intra-regional competition (addressed only marginally in the 1973 Treaty, in Article 30) through, inter alia, the development of micro and small enterprises (CARICOM 2001: Articles 51-56), the Revised Treaty still pursues productive complementation, i.e. regional production chains and cooperation in research and development (CARICOM 2001: Article 52, also 54, 57). In addition, the CARICOM Development Fund for confronting international, socio-spatial and sectoral structural asymmetries (uneven development), established in 2008, was activated in 2009 (CARICOM 2008; SELA 2011).

This has been accompanied by an intensification of relations with the Cuban Revolution. In Cuba, the restructuring of domestic production from 1986 onward was accompanied by a diversification of international relations, whereby South-South cooperation became a key strategy in a counter-dependency foreign policy (Byron 2000; Cotman 2000; Erisman 1991, 2006; Furtak 1985:343-344). Between 1987 and 1992 a series of high-level meetings and summits (re)established economic cooperation between Cuba and CARICOM member states and entrepreneurs (Cotman 2000:207; González Núñez 1997:81). With the creation of a CARICOM-Cuba Joint Commission in 1993, which met regularly throughout the 1990s, a comprehensive South-South agenda became instituted, comprising agricultural, biotechnological, environmental, trade, social, cultural, educational, health, sports, tourism, and political cooperation and solidarity (Byron 2000, 2015; Cotman 2006). As a manifestation of socio-spatial dialectics, the context for this was set by neoliberalism having failed to significantly increase intraregional trade and CARICOM's extraregional export market share (Cotman 2000, 2006:139; also Girvan 2011): "by the end of 1991", Erisman (1995:56) states, "U.S. imports from CARICOM members were a mere $63 \%$ of 1984 values while the trade performance vis-à-vis the United States of the entire CBI [Caribbean Basin Initiative] region during this period was below the Third World average". Subsequently, following the 2000 Cuba-CARICOM Trade and Economic Cooperation Agreement (under revision in 2015; see CARICOM 2014), at the first of the triannually convened Cuba-CARICOM Summits in 2002 the

\footnotetext{
${ }^{9}$ Jessica Byron, email communication, 8 July 2015.
} 
essence of South-South cooperation was elucidated by declaring that "the negative aspects of globalisation and trade liberalisation require bold and innovative initiatives to reverse the deterioration in the terms of trade between developed and developing countries" (CARICOM 2002).

Twelve years later, the "will to strengthen South-South cooperation, as an expression of solidarity among our countries" was reaffirmed (CARICOM 2014: Point 3).

Despite the "predominant role" of the private sector in CARICOM state economic policy (Cotman 2010:201), and even though Cuba-CARICOM trade was found to be "insignificant" in the early 2000s (Cotman 2010:210), CARICOM's

"counterdependency foreign policy", which during the 2000s was largely limited to Cuban altruistic provision of health, education and construction/housing (Cotman 2006:126), has become significantly strengthened through cooperation with ALBATCP/Petrocaribe:

[b]y 2008 Petrocaribe had become by far the largest provider of concessionary finance in absolute terms to the recipient countries; exceeding the flows of development assistance from the EU, USAID [United States Agency for International Development], the IADB [Inter-American Development Bank] and the World Bank (Girvan 2011:163).

By 2010, ALBA-TCP "aid" to Antigua and Barbuda, Dominica and St Vincent and the Grenadines - which also are CARICOM members (see Appendix 1)-amounted to US\$145 million compared with EU “aid" of US\$27 million during 2008-2013 (Girvan 2011:173). In 2014/2015 nine regional development projects are coordinated triangularly by Cuba, CARICOM and the respective CARICOM member in whose territory the project is implemented (Byron 2015). This includes a school for visual and performing arts and a training centre for people with disabilities, implemented by Cuba-Jamaica-CARICOM and Cuba-Guyana-CARICOM, respectively (Byron 2015).

\section{MERCOSUR}

Established in 1991 as a neoliberal "open regionalism", by the late 1990s asymmetries within MERCOSUR had aggravated both inter-nationally (between the member nations) and socio-spatially, with economic activity concentrated in urban centres along the São Paulo-Buenos Aires "axis" (Mellado and Gajate 1998). With the newly elected leftist governments of Argentina and Brazil (both from 2003) and Uruguay (from 2005), in conjunction with the adhesion of the Bolivarian Republic of Venezuela as a full member in 2006 (fully ratified by 2012), however, MERCOSUR underwent a "paradigm shift" as trade became complemented by the social and productive dimensions (Briceño Ruiz 2012:175). Specifically, a "Social MERCOSUR" (equity promotion and regional welfare policies, including health and housing), a "Sociolabour MERCOSUR" (individual and collective labour rights), and a "Education MERCOSUR" (education cooperation and integration) became structurally integrated. Questioning the Washington Consensus and "overcoming neoliberalism" (MERCOSUR 2006: Point 3) became part of a "shared vision" on which basis "Mercosur developed an assertive position in its negotiations with the developed centre countries and an active policy aimed at expanding South American integration while taking into consideration existing asymmetries" (Christensen 2007). 
While a High Level Group for the Elaboration of a South-South Cooperation Programme (Grupo de Alto Nivel para la Elaboración de un Programa de Cooperación Sur-Sur, GANASUR) has been established on Venezuelan initiative (MERCOSUR 2008), in 2014 the Group for International Cooperation (Grupo de Cooperación Internacional, GCI) was working towards "the updating of the normative heritage of the MERCOSUR International Cooperation Policy, whose basis are the principles that guide South-South Cooperation: solidarity, horizontality, nonconditionality, consensus, and mutual benefit" (MERCOSUR 2014c: Point 17). Previously, the South-South principle of complementarity became associated with the creation of productive synergies, and cooperation with production, technology and knowledge exchange/transfer (e.g. MERCOSUR 2012a, 2012b). The idea of "solidarity economy" (MERCOSUR 2006: Point 12) became consolidated in the Strategic Plan for Social Action (MERCOSUR 2012a:63), which frames the Social and Solidarity Economy for Regional Integration programme financed through the MERCOSUR Structural Convergence Fund (Fondo para la Convergencia Estructural del MERCOSUR, FOCEM). Designed as the "principal tool of solidarity within the region to fight the asymmetries" (MERCOSUR 2013: Point 33), this takes two distinct forms: first, inter-nationally, funds are redistributed from the relatively more developed to the less developed economies, calculated on the basis of the member states' GDPs (see César 2015). Between 2006 (when the Fund became operational) and December 2015, US\$1306 million in regular and voluntary contributions were provided by Brazil (72.5\%), Argentina (19.1\%), Venezuela (6.2\%), Uruguay (1.4\%) and Paraguay (0.7\%), and redistributed to Paraguay (43.70\%), Uruguay $(29.15 \%)$ and Venezuela, Argentina and Brazil at equal shares of 9.05\% (César 2015). Second, socio-spatially public policies are mobilised to redistribute resources from the "dynamic centres" (César 2015) in the MERCOSUR territorial space to historically marginalised zones, to "contribute to reducing the severe social, economic, productive and commercial asymmetries between the two sides of the border, to contain the rural exodus (of especially young people), [and to] restrain contraband and labour exploitation" (MERCOSUR 2016). As a key dimension of MERCSOUR South-South cooperation, transnational cross-border cooperation and integration is strategically promoted, producing distinct scales (such as the Brazil-Venezuela "Special Border Regime"; see Muhr 2016b) by participation of both social and political forces: schools; universities; small and medium enterprises and cooperatives; municipal, federal state and national governments; and MERCOSUR institutions.

With annual contributions of only $0.008 \%$ of the MERCOSUR members' GDPs (César 2015), the FOCEM appears insignificant. However, for Argentina and Brazil FOCEM ranges fourth and fifth, respectively, among multilateral cooperation institutions, while for Paraguay it has become the most important and for Uruguay the second most important partner (Rodríguez Patrinós 2014). Between 2006 and 2014, FOCEM approved funding for 45 projects, principally in the area of structural convergence (economically and socio-spatially), but also for social cohesion (especially targeting the border zones), and for the strengthening of the institutional structure and the integration process (César 2015; Rodríguez Patrinós 2014). Sectors include housing, transport, energy, productive integration (chains and networks), biosecurity, capacity building, sanitation and health, and education, whereby (as in ALBA-TCP and CARICOM) micro, small and medium community-based enterprises and cooperatives are primarily promoted (MERCOSUR 2012a; Rodríguez Patrinós 2014). 
In sum, this historical exploration of the South-South cooperation dimension in the ALBA-TCP/Petrocaribe, CARICOM and MERCOSUR served to show that rather than being separate, incompatible or conflicting political projects, South-South cooperation is a shared commonality or unifying dimension, which explains their integration and convergence as complementary economic zones. Examples that further illustrate trans-regional (i.e. traversing different regionalisms) South-South cooperation relations are the Brazil-CARICOM Summit of April 2010, when 60 cooperation agreements were signed between the parties (SELA 2010); and MERCOSUR South-South cooperation with Haiti, which has involved the implementation of 321 development projects within a human rights rationale (in a broad sense as including economic, social and cultural besides political rights) in Haiti between 2005 and 2012, plus another 159 projects in 2013 (IPPDH 2014).

Methodologically, local manifestations of South-South cooperation-material and discursive practices, processes and relations - are not isolated instances, but are structurally interconnected across territories in the production of space/scale. Examples of such cross-territorial, pluri-scalar inter- and transnational processes and relations include the aforementioned Brazil-Cuba medical cooperation, which provides solidarity health care to structurally excluded populations in peripheral locations in Brazil (thus alleviating uneven development); and the ALBATCP/Petrocaribe grandnational enterprises and development funds that are operational at different local and national scales in territories that are also CARICOM members. Other examples can be added: the multi-state teleSUR news network (Argentina, Bolivia, Cuba, Ecuador, Nicaragua, Uruguay, Venezuela), which integrates local scale community media in a counter-hegemonic information structure that operates at national, inter- and transnational, regional and global scales (Villazana 2013; $\mathrm{http}: / /$ www.telesurtv.net); literacy points (as a distinct local scale) set up in national ALBA-TCP/Petrocaribe, CARICOM and MERCOSUR member territories, coordinated also at national, inter- and transnational and regional scales (Muhr 2015b); and newly created state transport systems that have established, inter alia, direct sea and air connections between such places as Caracas and Managua and Caribbean capitals (SELA 2015:28-29). As a form of material practice (see Massey 2005:119), such connectivities not only produce relational space but simultaneously transform relative space (the relative locations of these places to each other), as these globally peripheral places had mostly only been indirectly connected via the USA territory. The conclusion extends this argument, showing that a socio-spatial methodology also facilitates "seeing" the production of a socialist counter-space.

\section{Conclusion: South-South Cooperation and the Production of a Socialist Counter- Space}

Overcoming the "state-as-a-monolith centric view" (Moisio and Paasi 2013:256) and the "territorial trap" (Agnew 1994), a relational ontology entails abandoning methodologically nationalist categorisations: rather than asking whether a particular "country" is socialist, transition to socialism implies a "coexistence of capitalist and socialist modes of accumulation" (Ludlam 2012:43). For example, far from being homogenous absolute spaces, in such territories as the El Salvadoran and Nicaraguan global capitalist and ALBA-TCP/Petrocaribe networks of petrol stations coexist 
(Muhr 2012). As the perhaps most cogent illustration of the intertwinedness of capitalist and socialist practices and relations in socialist transformation, the grandnational enterprises (as previously indicated) are multi-state regional scale coordinators of local and national scale productive and distributive private, mixed (bistate) and social economy firms (Aponte-García 2014). As argued, the sociocultural practices associated with different political projects produce a "simultaneous multiplicity of spaces" (Massey 1994:3) that interpenetrate and superimpose one another and are permanently being reconfigured or reconstructed (Lefebvre 1991:86). A socio-spatial approach thus views structural transformation towards socialism as "the interrelation" of the emerging structure "with the accumulated results of the old" (Massey 1995:117) — a dialectical interplay between inherited ("path-dependent") geographies of spatial organisation and emergent projects to reconfigure such historical spatial structures (Brenner 2004:90, 110, 112).

While social relations of solidarity and redistribution have been considered distinctly different from capitalist exchange (Gibson-Graham 2006: Chapter 3; Polanyi 2001), South-South cooperation is not per se non-capitalist as it involves private surplus value appropriation. However, as suggested with respect to Cuban socialist internationalism and fair trade as integral to South-South cooperation within the envisioned complementary economic zones, ${ }^{10}$ practices of solidarity do undermine the competitive market and profit maximisation logic while prioritising use value over exchange value. Accordingly, state interventionist practices associated with "distributive socialism" (Harvey 2011:224-225) include the rights-based equityenhancing deprivatisation and decommoditisation of basic goods and services, including cooking gas, education (especially tertiary education and literacy campaigns), electricity, food, health, housing and drinking water (e.g. ALBA-TCP 2014; Michelutti 2012; Muhr 2013, 2015b, 2016b; Petrocaribe 2015). Local scale instances of state-promoted micro, small and medium family and workers-run enterprises and cooperatives are examples of a democratisation (collectivisation/socialisation) of ownership and management, as in the "Communal Economic System" in Venezuela (Yaffe 2015); the Nicaraguan food security structure around the re-activated state enterprise ENABAS (Empresa Nicaragüense de Alimentos Básicos); the Acajutla Water Infrastructure Project in El Salvador and the Artibonite Valley Project for the Intensification of Rice Production in Haiti (Petrocaribe 2015:27); and the co-management of the Latin American Agroecological Institute "Paulo Freire" (Instituto Agroecológico Latinoamericano "Paulo Freire", IALA) in Venezuela, by the Bolivarian Republic of Venezuela, the Brazilian Landless Rural Workers Movement (Movimento dos Trabalhadores Rurais Sem Terra, MST), and Vía Campesina (Muhr 2013).

If uneven development is "both the product and the geographical premise of capitalist development" (Smith 2010:206), "the equalization of conditions and levels of development lays the basis for the development of socialism" (Smith 2010:204). As shown, the ALBA-TCP/Petrocaribe, CARICOM and MERCOSUR redistributive structural convergence development funds are key mechanisms in a socio-spatial redistribution of wealth (and power). At urban scales, state driven de-gentrification processes are integral to the production of this socialist counter-space. In Caracas, for

\footnotetext{
${ }^{10}$ For example, fair trade exchanges within Petrocaribe (concessional compensation of Venezuelan petroleum and derivatives deliveries in goods and services) totalled US $\$ 3471$ million by May 2015 (Petrocaribe 2015:19).
} 
instance, "expanding rights to the city center [has been] aimed at reversing the spatial segregation and exclusion of the urban poor and engendering new cultural values in urban space" (Humphrey and Valverde 2014:155). This production of relational space, and reconfiguration of relative spatial structures, involves the (re)conversion of commercialised territorial spaces into public ones (squares, pedestrian precincts, avenues, buildings) by, for instance, installing state/worker run cafes, free-of-charge performance, visual arts and cinematic spaces, and by connecting the city centre with working class neighbourhoods through public transport infrastructure. To be sure, such socialist relations have not been generalised in any of the national and regional territories discussed, and there is nothing deterministic about the construction of this socialist counter-space. This is important considering the restrengthening of authoritarian neoliberalism via the election of President Macri in Argentina in 2015, and what the progressive forces perceive as a "parliamentary-judicial coup d'état" against Brazilian President Rousseff in 2016 (ALBA-TCP 2016). Undoubtedly, such government changes alter the politics of cooperation in Latin America-Caribbean, and the ALBA-TCP/Petrocaribe-CARICOM-MERCOSUR Complementary Economic Zone in particular may never become instituted. Such developments, however, do not undermine the relevance of the methodological argument advanced in this article. Namely, that of "coexisting heterogeneity" (Massey 2005:9-11), that there are "spatial differences" and that "actually-existing 'others'... might have their own stories to tell" (Massey 1999:35) — stories obliterated by the dominant international studies literatures. 
Appendix 1: Latin America-Caribbean regionalisms: overlapping memberships, 2016 (source: compiled by author)

\begin{tabular}{|c|c|c|c|c|c|}
\hline & & MERCOSUR & ALBA-TCP & Petrocaribe & CARICOM \\
\hline 1 & Argentina & + & & & \\
\hline 2 & Brazil & + & & & \\
\hline 3 & Paraguay & + & & & \\
\hline 4 & Uruguay & + & & & \\
\hline 5 & Bolivia & $\begin{array}{c}\stackrel{+}{\text { (in process of }} \\
\text { ratification) }\end{array}$ & + & & \\
\hline 6 & Ecuador & & + & & \\
\hline 7 & Venezuela & + & + & + & \\
\hline 8 & Cuba & & + & + & \\
\hline 9 & Nicaragua & & + & + & \\
\hline 10 & Antigua and Barbuda & & + & + & + \\
\hline 11 & Dominica & & + & + & + \\
\hline 12 & Grenada & & + & + & + \\
\hline 13 & Saint Lucia & & + & + & + \\
\hline 14 & St Kitts and Nevis & & + & + & + \\
\hline 15 & St Vincent and the Grenadines & & + & + & + \\
\hline 16 & Barbados & & & + & + \\
\hline 17 & The Bahamas & & & + & + \\
\hline 18 & Guyana & & & + & + \\
\hline 19 & Haiti & & & + & + \\
\hline 20 & Jamaica & & & + & + \\
\hline 21 & Suriname & & & + & + \\
\hline 22 & Dominican Republic & & & + & \\
\hline 23 & El Salvador & & & + & \\
\hline 24 & Guatemala & & & + & \\
\hline 25 & Honduras & & & + & \\
\hline 26 & Belize & & & & + \\
\hline 27 & Montserrat & & & & + \\
\hline 28 & Trinidad and Tobago & & & & + \\
\hline
\end{tabular}

\section{Acknowledgements}

Earlier versions of this article were presented as "Continuity After Chávez: The Construction of an ALBA/MERCOSUR/UNASUR South-South Cooperation Space" at the workshop "Latin America: New Security Configurations in a Strategic Emerging Region”, Institute of Latin American Studies (ILAS), London, 19 September 2014; as "The ALBA-TCP/PETROCARIBECARICOM-MERCOSUR Complementary Economic Zone" at the conference "Ten Years of the ALBA: Progress, Problems and Prospects", Institute of Latin American Studies (ILAS), London, 26 February 2015; and as "The ALBA-TCP: Setting the Standards for a Latin American and Caribbean South-South Cooperation Space?", at the XXXIII Latin American Studies Association (LASA) Congress, San Juan, Puerto Rico, 29 May 2015. I would like to thank LASA for the award of a competitive conference travel grant. My gratitude extends to Jessica Byron (University of the West Indies) for constructive comments on a draft version of this article, as well as to three anonymous peer reviewers for their constructive engagement and probing of my arguments. The usual disclaimers apply. 


\section{References}

Agnew J A (1994) The territorial trap: The geographical assumptions of international relations theory. Review of International Political Economy 1(1):53-80

Agnew J A (2013) Arguing with regions. Regional Studies 47(1):6-17

ALBA-TCP (2014) ALBA-PTA Management Report 2004-2014: Ten Years Consolidating Solidarity and Integration Among the Peoples of Our America. Caracas: ALBA-TCP http://albatcp.org/public/documents/decimo/English/Management_report.pdf (last accessed 4 October 2016)

ALBA-TCP (2015) “Declaración Final de la IV Reunión Extraordinaria del Consejo Político del ALBA-TCP." 10 August, Caracas

ALBA-TCP (2016) "Special Communiqué: The ALBA-TCP strongly rejects coup against Brazil." 12 May, Caracas

Alvarez González E C (2000) "Descentralización y diversificación en la economía cubana: nuevas bases para la cooperación internacional." Paper presented to the XXII LASA Congress, 16-18 March, Miami

Alzugaray Treto C (2006) Cuban foreign policy during the "Special Period": Interests, aims, and outcomes. In H M Erisman and J M Kirk (eds) Redefining Cuban Foreign Policy: The Impact of the "Special Period" (pp 49-71). Gainesville: University Press of Florida

Amelina A, Faist T, Glick Schiller N and Nergiz D D (2012) Methodological predicaments of cross-border studies. In A Amelina and T Faist (eds) Beyond Methodological Nationalism: Research Methodologies for Cross-Border Studies (pp 1-19). New York: Routledge

Anton A and Schmitt R (2007) Toward a New Socialism. Lanham: Lexington

Aponte-García M (2014) El Nuevo Regionalismo Estratégico: Los Primeros 10 Años del ALBA-TCP. Buenos Aires: CLACSO

Ayllón B and Ojeda T (2013) La Cooperación Sur-Sur y Triangular en América Latina. Madrid: Catarata

Ayllón B, Ojeda T and Surasky J (2014) Cooperación Sur-Sur: Regionalismos e Integración en América Latina. Madrid: Catarata

Bitar S (1988) Neo-conservatism versus neo-structuralism in Latin America. CEPAL Review 34:45-62

Bolivarian Republic of Venezuela (2001) Lineas Generales del Plan de Desarrollo Económico y Social de la Nación 2001-2007. Caracas: República Bolivariana de Venezuela

Brenner N (2004) New State Spaces: Urban Governance and the Rescaling of the State. Oxford: Oxford University Press

Brenner N (2010) A thousand leaves: Notes on the geographies of uneven spatial development. In R Keil and R Mahon (eds) Leviathan Undone? Towards a Political Economy of Scale (pp 27-49). Vancouver: University of British Columbia Press

Briceño-Ruiz J (2010) From the South American Free Trade Area to the Union of South American Nations: The transformations of a rising regional process. Latin American Policy 1(2):208-229

Briceño Ruiz J (2012) New left governments, civil society, and constructing a social dimension in Mercosur. In B Cannon and P Kirby (eds) Civil Society and the State 
in Left-Led Latin America (pp 173-186). London: Zed.

Byron J (2000) Square dance diplomacy: Cuba and CARIFORUM, the European Union, and the United States. European Review of Latin American and Caribbean Studies 68(April):23-45

Byron J (2015) “A New Era of South-South Cooperation: Development Partnerships Among CARICOM Countries, Cuba and Venezuela, 2005-2015." Paper presented to the XXXIII LASA Congress, 30 May, San Juan

Califano A (2015) Las empresas grannacionales. In M Aponte-García and G Amézquita Puntiel (eds) El ALBA-TCP: Origen y Fruto del Nuevo Regionalismo Latinoamericano y Caribeño (pp 109-144). Buenos Aires: CLACSO

Caporaso J A (1978) Dependence, dependency, and power in the global system: A structural and behavioral analysis. International Organization 32(1):13-43

CARICOM (1973) "Treaty Establishing the Caribbean Community." 4 July, Chaguaramas

CARICOM (2001) Revised Treaty of Chaguaramas Establishing the Caribbean Community, Including the CARICOM Single Market and Economy. Georgetown: CARICOM. http://caricom.org/about-caricom/who-we-are/our-governance/therevised-treaty/ (last accessed 4 October 2016)

CARICOM (2002) "The Havana Declaration on the Thirtieth Anniversary of the Establishment of Diplomatic Relations between Member States of the Caribbean Community and the Republic of Cuba." 8 December, Havana

CARICOM (2008) "Agreement Relating to the Operation of the CARICOM Development Fund." 4 July, Georgetown

CARICOM (2014) "Declaración de La Habana en Ocasión de la V Cumbre CARICOM-Cuba." 8 December, Havana

CEPAL (2016) Panorama Social de América Latina 2015. Santiago: Comisión Económica para América Latina

César G R de C (2015) FOCEM: Evaluación sobre su desempeño y posibilidades de reforma. Asunción: OBEI/CADEP

Chaturvedi S (2012) Development cooperation: Contours, evolution, and scope. In S Chaturvedi, T Fues and E Sidiropoulos (eds) Development Cooperation and Emerging Powers (pp 13-36). London: Zed

Chávez Frías H R (2005) " ¡No demos descanso a nuestros brazos, ni reposo a nuestras almas hasta salvar la humanidad!" Speech at the 60th UN General Assembly, New York

Christensen S F (2007) "South American Regional Integration: Two Moments in Mercosur's Integration Trajectory." CCS Research Series Working Paper No. 5, Aalborg University. http://vbn.aau.dk/files/13002797/ccis_working_paper_no._5 (last accessed 9 July 2015)

Cotman J W (2000) Caribbean convergence: Cuba-CARICOM relations through 1995. In E Linger and J Cotman (eds) Cuban Transitions at the Millennium (pp 205-224). Largo: International Development Options

Cotman J W (2006) Caribbean convergence: Contemporary Cuba-CARICOM relations. In H M Erisman and J M Kirk (eds) Redefining Cuban Foreign Policy: The Impact of the "Special Period" (pp 121-149). Gainesville: University Press of Florida

Cotman J W (2010) The Havana Consensus: Cuba's ties with five CARICOM states. In K O Hall and M Chuck-A-Sang (eds) CARICOM: Policy Options for International Engagement (pp 200-217). Kingston: Ian Randle

DeMartino G (2003) Realizing class justice. Rethinking Marxism 15(1):1-31 
De Sá e SilvaM M (2009) South-South cooperation: Past and presentconceptualization and practice. In L Chisholm and G Steiner-Khamsi (eds) SouthSouth Cooperation in Education and Development (pp 39-59). New York: Teachers College Press

De Vos P, De Ceukelaire W, Bonet M and Van der Stuyft P (2007) Cuba's international cooperation in health: An overview. International Journal of Health Services 37(4):761-776

Domínguez J I (1989) To Make a World Safe for Revolution: Cuba's Foreign Policy. Cambridge: Harvard University Press

ECLAC (1994) Open Regionalism in Latin America and the Caribbean: Economic Integration as a Contribution to Changing Production Patterns with Social Equity. Santiago: Economic Commission for Latin America. http://www.eclac.org/publicaciones/xml/7/4747/lcg1801i.html (last accessed 3 February 2008)

Emirbayer M (1997) Manifesto for a relational sociology. American Journal of Sociology 103(2):281-317

Erisman H M (1991) Cuban development aid: South-South diversification and counterdependency politics. In H M Erisman and J M Kirk (eds) Cuban Foreign Policy Confronts a New International Order (pp 139-165). London: Lynne Rienner

Erisman H M (1995) Evolving Cuban-CARICOM relations: Comparative cost/benefit analysis. New West Indian Guide/Nieuwe West-Indische Gids 69(1/2):45-66

Erisman H M (2006) Between a rock and a hard place: Survival strategy in Cuba's new foreign policy. In H M Erisman and J M Kirk (eds) Redefining Cuban Foreign Policy: The Impact of the "Special Period" (pp 1-22). Gainesville: University Press of Florida

Federative Republic of Brazil (2007) Política Nacional de Desenvolvimento Regional: Sumário Executivo. Brasilia: Ministério da Integração Nacional

Ffrench-Davis R (1988) An outline of a neo-structuralist approach. CEPAL Review 34:37-44

Furtak R K (1985) Cuba: un cuarto de siglo de política exterior revolucionaria. Foro Internacional 25(4):343-361

Gardini G L (2015) Towards modular regionalism: The proliferation of Latin American cooperation. Revista Brasileira de Politica Internacional 58(1):210-229

Gibson-Graham J K (2006) A Postcapitalist Politics. Minneapolis: University of Minnesota Press

Girvan N (2011) Is ALBA a new model of integration? Reflections on the CARICOM experience. International Journal of Cuban Studies 3(2/3):157-180

González Núñez G (1997) International relations between Cuba and the Caribbean in the 1990s. Latin American Perspectives 24(5):81-95

Grayson G W (1985) The San José oil facility: South-South cooperation. Third World Quarterly 7(2):390-409

Harvey D (1990) The Condition of Postmodernity. Oxford: Blackwell

Harvey D (1996) Justice, Nature, and the Geography of Difference. Oxford: Blackwell

Harvey D (2000) Spaces of Hope. Edinburgh: Edinburgh University Press

Harvey D (2005) A Brief History of Neoliberalism. New York: Oxford University Press

Harvey D (2006a) Space as a key word. In N Castree and D Gregory (eds) David 
Harvey: A Critical Reader (pp 270-293). Oxford: Blackwell

Harvey D (2006b) Spaces of Global Capitalism: Towards a Theory of Uneven Geographical Development. London: Verso

Harvey D (2010) "Organizing For the Anti-Capitalist Transition." Paper presented to the World Social Forum, 25-29 January, Porto Alegre.

http://davidharvey.org/2009/12/organizing-for-the-anti-capitalist-transition/ (last accessed 8 December 2015)

Harvey D (2011) The Enigma of Capital and the Crises of Capitalism. London: Profile

Hickling-Hudson A, Corona González J, Lehr S and Majoli Viani M (2012) The Cuban Revolution and internationalism: Structuring education and health. In A Hickling-Hudson, J Corona González and R Preston (eds) The Capacity to Share: A Study of Cuba's International Cooperation in Educational Development (pp 1334). New York: Palgrave Macmillan

Higginbottom A (2013) The political economy of foreign investment in Latin America: Dependency revisited. Latin American Perspectives 40(3):184-206

Howitt R (1993) "A world in a grain of sand": Towards a reconceptualisation of geographical scale. Australian Geographer 24(1):33-44

Howitt R (1998) Scale as relation: Musical metaphors of geographical scale. Area 30(1):49-58

Humphrey M and Valverde E (2014) Hope and fear in Venezuelan democracy. In L F Angosto-Ferrández (ed) Democracy, Revolution, and Geopolitics in Latin America (pp 147-176). New York: Routledge

INIDE (2015) "Presentación de resultados de la encuesta de medición de nivel de vida 2014. Palabras de Ovidio Reyes, Presidente del Banco Central de Nicaragua." 6 October, Managua

IPPDH (2014) MERCOSUR, UNASUR y Haití: Cooperación en Derechos Humanos. Buenos Aires: Instituto de Políticas Públicas en Derechos Humanos del MERCOSUR

Jessop B, Brenner N and Jones M (2008) Theorizing socio-spatial relations. Environment and Planning D: Society and Space 26(3):389-401

Jonas A (1994) The scale politics of spatiality. Environment and Planning D: Society and Space 12(3):257-264

Kirk J M, Kirk E J and Walker C (2015) Mais Médicos: Cuba's medical internationalism programme in Brazil. Bulletin of Latin American Research doi:10.1111/blar.12418

Lefebvre H (1991) The Production of Space (trans D Nicholson-Smith). Oxford: Blackwell

Ludlam S (2012) Aspects of Cuba's strategy to revive socialist development. Science and Society 26(1):41-65

MacKinnon D (2010) Reconstructing scale: Towards a new scalar politics. Progress in Human Geography 35(1):21-36

Mansfield B (2005) Beyond rescaling: Reintegrating the "national" as a dimension of scalar relations. Progress in Human Geography 29(4):458-473

Marston S A (2000) The social construction of scale. Progress in Human Geography 24(2):219-242

Marston S A and Smith N (2001) States, scales, and households: Limits to scale thinking? A response to Brenner. Progress in Human Geography 25(4):615-619

Martins H (1974) Time and theory in sociology. In J Rex (ed) Approaches to Sociology: An Introduction to Major Trends in British Sociology (pp 246-294). 
London: Routledge and Kegan Paul

Massey D (1978) Regionalism: Some current issues. Capital and Class 6:106-125

Massey D (1987) Nicaragua. Milton Keynes: Open University Press

Massey D (1994) Space, Place, and Gender. Minneapolis: University of Minnesota

Massey D (1995) Spatial Divisions of Labour (2nd edn). New York: Routledge

Massey D (1999) Power-Geometries and the Politics of Space-Time. Heidelberg: University of Heidelberg

Massey D (2005) For Space. London: Sage

Mawdsley E (2012) From Recipients to Donors: Emerging Powers and the Changing Development Landscape. London: Zed

Mellado N and Gajate R (1998) La inclusión de la regiones en el MERCOSUR. Aportes para la Integración Latinoamericana 4(4):91-123

MERCOSUR (2006) “Declaración Final.” 14 December, Brasilia

MERCOSUR (2008) "XXXV Reunión Ordinaria del Consejo del Mercado Común." MERCOSUR/CMC/ACTA No. 01/08

MERCOSUR (2012a) Plan Estratégico de Acción Social. Asunción: Instituto Social del MERCOSUR

MERCOSUR (2012b) "Comunicado Conjunto de los Presidentes de los Estados Partes del MERCOSUR.” 29 June, Mendoza

MERCOSUR (2013) "Comunicado Conjunto de los Presidentes de los Estados Partes del MERCOSUR.” 12 July, Montevideo

MERCOSUR (2014a) "Declaración Conjunta de los Estados Partes del Mercado Común del Sur (MERCOSUR) para Promover el Establecimiento de una Zona Económica Complementaria entre los Estados Partes del Mercado Común del Sur (MERCOSUR), los Países Miembros de la Alianza Bolivariana para los Pueblos de Nuestra América (ALBA-TCP), los Países Miembros de PETROCARIBE y los Miembros de la Comunidad del Caribe (CARICOM)." 29 July, Caracas

MERCOSUR (2014b) "Informe de la Presidencia Pro Témpore Venezolana del MERCOSUR (PPTVEN), July 2013-July 2014.” Acta No. 01/14, XLVI Ordinary Meeting of the Council of the Common Market, 28 July, Caracas

MERCOSUR (2014c) "Comunicado Conjunto de las Presidentas y los Presidentes de los Estados Partes del MERCOSUR.” 17 December, Paraná

MERCOSUR (2016) Economía social y solidaria. Asunción: Instituto Social del MERCOSUR. http://ismercosur.org/proyectos/economia-social-y-solidaria/ (last accessed 15 June 2016)

Michelutti L (2012) Small-Scale Farmers Under Socialist Governments: Venezuela and the ALBA People's Trade Agreement. London: IIED/Hivos

MINCI (2004) Desarrollo Endógeno. Desde Adentro, Desde la Venezuela Profunda. Caracas: Ministerio de Comunicación e Información

Moisio S and Paasi A (2013) Beyond state-centricity: Geopolitics of changing state spaces. Geopolitics 18(2):255-266

Moore A (2008) Rethinking scale as a geographical category: From analysis to practice. Progress in Human Geography 32(2):203-225

Muhr T (2008) "Venezuela: Global Counter-Hegemony, Geographies of Regional Development, and Higher Education For All." Unpublished PhD thesis, University of Bristol. https://www.academia.edu/3343656/Venezuela_Global_CounterHegemony_Geographies_of_Regional_Development_and_Higher_Education_For All._University_of_Bristol_2008 (last accessed 4 October 2016)

Muhr T (2010) TINA go home! ALBA and re-theorizing resistance to global capitalism. Cosmos and History: The Journal of Natural and Social Philosophy 
$6(2): 27-54$

Muhr T (2011) Venezuela and the ALBA: Counter-Hegemony, Geographies of Integration and Development, and Higher Education For All. Saarbrücken: VDM

Muhr T (2012) The politics of space in the Bolivarian Alliance For the Peoples of Our America-Peoples' Trade Agreement (ALBA-TCP): Transnationalism, the organized society, and counter-hegemonic governance. Globalizations 9(6):767782

Muhr T (2013) The enigma of socialism. In T Muhr (ed) Counter-Globalization and Socialism in the 21st Century: The Bolivarian Alliance For the Peoples of Our America (pp 1-29). London: Routledge

Muhr T (2015a) "The ALBA-TCP: Setting the Standards for a Latin American and Caribbean Cooperation Space?" Paper presented at the XXXIII Latin American Studies Association (LASA) Congress, 29 May, San Juan. https://www.academia.edu/attachments/45990896/download_file?st=MTQ2NTEy MTMwNSw4NC4xNzAuMTk1Ljc1LDM4NTA4MDc\%3D\&s=swp-previewselector-dropdown (last accessed 4 October 2016)

Muhr T (2015b) South-South cooperation in education and development: The Yo, Sí Puedo literacy method. International Journal of Educational Development 43:126133

Muhr T (2016a) Beyond "BRICS": Ten theses on South-South cooperation in the 21 st century. Third World Quarterly 37(4):630-648

Muhr T (2016b) Equity of access to higher education in the context of South-South cooperation in Latin America: A pluri-scalar analysis. Higher Education 72(4):557-571

Nove A (1983) The Economics of Feasible Socialism. London: George Allen \& Unwin

Paasi A (2004) Place and region: Looking through the prism of scale. Progress in Human Geography 28(4):536-546

Petrocaribe (2015) Management Report. Puerto la Cruz: Petrocaribe. http://eeuu.embajada.gob.ve/index.php?option=com_docman\&task=doc_view\&gid $=162 \&$ Itemid $=91 \&$ lang $=$ en (last accessed 13 June 2016)

Petrocaribe (2016) "XVI Reunión del Consejo Ministerial de Petrocaribe." https://www.youtube.com/watch? $\mathrm{v}=\mathrm{x} 8 \mathrm{IKmpNn} 6 \mathrm{~s} 0$ (last accessed 4 October 2016)

PNUD (2003) Investigación sobre Ciencia, Tecnología y Desarrollo Humano en Cuba 2003. La Habana: Centro de Investigaciones de la Economía Mundial

Polanyi K (2001 [1944]) The Great Transformation. Boston: Beacon

Radice H (2009) The idea of socialism: From 1968 to the present-day crisis. Antipode 41(s1):27-49

Republic of Ecuador (2009) Plan Nacional de Desarrollo: Plan Nacional para el Buen Vivir 2009-2013. Construyendo un Estado Plurinacional e Intercultural. Quito: SENPLADES

Rodríguez Patrinós P (2014) El MERCOSUR: Nuevas formas de cooperación y coordinación política. In B Ayllón, T Ojeda and J Surasky (eds) Cooperación SurSur. Regionalismos e Integración en América Latina (pp 90-107). Madrid: Catarata

Santos B de S (2001) Nuestra America: Reinventing a subaltern paradigm of recognition and redistribution. Theory, Culture, and Society 18(2/3):185-217

SELA (2010) "Boletín 149: Sobre Integración de América Latina y el Caribe." April, Caracas. http://www.sela.org/attach/258/EDOCS/SRed/2010/05/T0236000040710-Boletin_de_integracion,_No._149,_abril_de_2010.pdf (last accessed 2 December 
2015)

SELA (2011) Las Asimetrías en los Procesos de Integración de América Latina y el Caribe. Caracas: Sistema Económico Latinoamericano y del Caribe

SELA (2015) Evolución del acuerdo de cooperación energética PETROCARIBE. Caracas: Sistema Económico Latinoamericano y del Caribe

Serbin A (2007) Entre UNASUR y ALBA: ¿otra integración (ciudadana) es posible? In A Serbin, P Isa-Contreras and L Peña (eds) Anuario de la Integración Regional de América Latina y el Caribe (pp 9-33). Buenos Aires: CRIES

Sheppard E (2012) Trade, globalization, and uneven development: Entanglements of geographical political economy. Progress in Human Geography 36(1):44-71

Smith N (1992a) Contours of a spatialized politics: Homeless vehicles and the production of geographical scale. Social Text 33:54-81

Smith N (1992b) Geography, difference, and the politics of scale. In J Doherty, E Graham and M Malek (eds) Postmodernism and the Social Sciences (pp 57-79). New York: Macmillan

Smith N (1997) The Satanic geographies of globalization: Uneven development in the 1990s. Public Culture 10(1):169-189

Smith N (2010) Uneven Development. Nature, Capital, and the Production of Space (3rd edn). London: Verso

Soja E (1989) Postmodern Geographies: The Reassertion of Space in Critical Social Theory. London: Verso

Sunkel O (1993) Development From Within. London: Lynne Rienner

Swyngedouw E (1997) Neither global nor local: "Glocalization" and the politics of scale. In K R Cox (ed) Spaces of Globalization: Reasserting the Power of the Local (pp 137-166). New York: Guildford

Taylor P J (1994) The state as container: Territoriality in the modern world-system. Progress in Human Geography 18(2):151-162

Tickell A and Peck J (2003) "Making Global Rules: Globalisation or Neoliberalisation?" Globalization and World Cities Research Network (GaWC) Research Bulletin 102. http://www.lboro.ac.uk/gawc/rb/rb102.html (last accessed 4 October 2016)

UNDP (2013) Human Development Report 2013: The Rise of the South: Human Progress in a Diverse World. New York: United Nations Development Programme

UNESCO (2014) BRICS: Building Education for the Future-Priorities for National Development and International Cooperation. Paris: United Nations Organization for Education, Science and Culture

Villazana L (2013) The politics of the audiovisual cultural revolution in Latin America and the Caribbean. In T Muhr (ed) Counter-Globalization and Socialism in the 21st Century: The Bolivarian Alliance for the Peoples of Our America (pp 188-202). London: Routledge

Yaffe H (2015) Venezuela: Building a socialist communal economy? International Critical Thought 5(1):23-41 